\title{
2La Paracentric Chromosomal Inversion and Overexpressed Metabolic Genes Enhance Thermotolerance and Pyrethroid Resistance in the Major Malaria Vector Anopheles gambiae
}

\author{
Sulaiman S. Ibrahim ${ }^{1,2, *(\mathbb{D}}$, Muhammad M. Mukhtar ${ }^{2}{ }^{(0}$, Abdullahi Muhammad ${ }^{1}$ and Charles S. Wondji ${ }^{1}$ \\ 1 Vector Biology Department, Liverpool School of Tropical Medicine, Pembroke Place, Liverpool L3 5QA, UK; \\ abdullahi.muhammad@lstmed.ac.uk (A.M.); charles.wondji@lstmed.ac.uk (C.S.W.) \\ 2 Department of Biochemistry, Bayero University, PMB 3011, Kano 700241, Nigeria; \\ muhammadmahemukhtar@gmail.com \\ * Correspondence: suleiman.ibrahim@lstmed.ac.uk; Tel.: +44-74-4044-3871
}

\section{check for} updates

Citation: Ibrahim, S.S.; Mukhtar, M.M.; Muhammad, A.; Wondji, C.S. 2La Paracentric Chromosomal Inversion and Overexpressed Metabolic Genes Enhance Thermotolerance and Pyrethroid Resistance in the Major Malaria Vector Anopheles gambiae. Biology 2021, 10, 518. https://doi.org/10.3390/ biology10060518

Academic Editor: Christian Doerig

Received: 26 March 2021

Accepted: 7 June 2021

Published: 10 June 2021

Publisher's Note: MDPI stays neutral with regard to jurisdictional claims in published maps and institutional affiliations.

Copyright: (c) 2021 by the authors. Licensee MDPI, Basel, Switzerland. This article is an open access article distributed under the terms and conditions of the Creative Commons Attribution (CC BY) license (https:/ / creativecommons.org/licenses/by/ $4.0 /)$.
Simple Summary: While shifts in temperature may promote the spread of insects, exacerbating the intensity of vector-borne diseases like malaria, very high temperatures exert deleterious effects in insect vectors, forcing them to evolve/adapt genetically. These genetic adaptations may facilitate insecticide resistance through common genes involved in both processes. Here, the impact of thermal tolerance on pyrethroid resistance in the major malaria vector Anopheles gambiae s.l. from four localities spanning the savanna and sub-Sahel of northern Nigeria was investigated. In all four localities, An. coluzzii and An. gambiae s.s. were the only malaria vectors found. The populations were highly thermotolerant, with $\sim 50 \%$ of mosquitoes in two sites surviving $44{ }^{\circ} \mathrm{C}$. Thermotolerant larvae and adult mosquitoes (survivors of $44{ }^{\circ} \mathrm{C}$ ) were significantly more resistant to permethrin, suggesting that prior heat-hardening facilitates insecticide resistance. Thermal tolerance and permethrin resistance were found to be associated with the 2La rearrangement (a form of chromosomal inversion). Transcriptional analysis revealed six major genes commonly overexpressed in the highly thermotolerant mosquitoes and those resistant to permethrin, suggesting common mechanisms involved in thermotolerance and insecticide resistance. These findings highlight challenges associated with insecticide-based malaria vector control, stressing the need to take environmental variables and other pleiotropic mechanisms into account for the choice of control measures.

Abstract: Changes in global temperature are impacting the spread/intensity of vector-borne diseases, including malaria, and accelerating evolutionary/adaptive changes in vector species. These changes, including chromosomal inversions and overexpression and/or changes in allele frequencies of thermotolerance-associated genes, may facilitate insecticide resistance through pleiotropy. This study investigated the impact of thermotolerance on pyrethroid resistance in four populations of the malaria vector An. gambiae s.l., from the savanna/sub-Sahel of northern Nigeria. Anopheles coluzzii and An. gambiae s.s. were the only malaria vectors found, sympatric in all the sites, with the former species predominant. High thermotolerance was observed, with no mortality at $38^{\circ} \mathrm{C}$, and $\mathrm{LT}_{50}$ of $\sim 44^{\circ} \mathrm{C}$. Significantly high permethrin resistance was observed (mortality $<50 \%$ ) in $44{ }^{\circ} \mathrm{C}$ heat-hardened (exposure to an intermediately high temperature provides protection to a more severe temperature or insecticide) larvae from two sites, BUK and Pantami, compared with the control, and heat-hardened adult females from Auyo (mortality $=3.00 \% \pm 1.20, \chi^{2}=5.83, p<0.01$ ) compared with the control $(12.00 \% \pm 4.65)$. The $2 \mathrm{La}$ chromosomal inversion was detected at $\sim 50 \%$ in subset of larvae and $58 \%$ in subset of adult females genotyped. A significant association was observed ( $\mathrm{OR}=7.2, p<0.03$ ) between permethrin resistance and the $2 \mathrm{La} /+^{\mathrm{a}}$ rearrangement compared with $2 \mathrm{~L}+{ }^{\mathrm{a}} /+^{\mathrm{a}}$, in BUK larvae. For all sites, permethrin resistance correlated with $2 \mathrm{La} /$ a homozygosity in adult females $(R=5.02, p=0.01)$. qRT-PCR identified six genes commonly induced/overexpressed, including the heat shock protein 70 (AGAP004581) which was $2468 \times$ and $5 \times$ overexpressed in heat-hardened and permethrin-resistant females, respectively; trehalose-6-phosphate synthase (AGAP008227); and the ionotropic glutamate receptor genes, IR25a (AGAP010272) and IR21a (AGAP008511). This study highlights challenges 
associated with insecticide-based malaria vector control, and the epidemiological significance of taking climate variables into account for the design/choice of control measures.

Keywords: malaria; Anopheles; coluzzii; gambiae s.s.; 2La; chromosomal; inversion; thermotolerance; permethrin; resistance

\section{Introduction}

Weather and climate are among the drivers of Anopheles geographic range, intensity of transmission, and seasonality of malaria, with the burden of the disease projected to increase with climate change because of a greater geographic range of the Anopheles vector, shifts in phenology [1], an increase in the number of generations per year [2], a longer season, and/or an increase in the number of people at risk [3-5]. The populations of mosquito vectors are projected to shift, but with contrasting expansions and reductions depending on the degree of local warming and the ecology of the mosquito vectors [3], leading to regionally variable patterns $[5,6]$ different from the current ones.

Small ectotherms (such as mosquitoes) are constrained by the extrinsic thermal environments, from microclimates to regional climates [7], and are particularly sensitive to even daily temperature fluctuations [8]. Indeed, temperature has been shown to constrain mosquito development rate, egg to adult survival and mortality rate, modify biting rate and fecundity, regulate Plasmodium falciparum parasite development rate and vector competence in the two major malaria vectors Anopheles gambiae s.s. [9] and Anopheles stephensi [10]. Empirical evidence from $A n$. stephensi suggests a temperature optimum for transmission of $26^{\circ} \mathrm{C}$ (minimum and maximum of $17^{\circ} \mathrm{C}$ and $35^{\circ} \mathrm{C}$, respectively). Increasing environmental temperature during the larval stages impacts thermal performance. For example, in $A n$. gambiae s.s., an increase of $4{ }^{\circ} \mathrm{C}$ (e.g., from $23^{\circ} \mathrm{C}$ to $27^{\circ} \mathrm{C}$, etc), $8^{\circ} \mathrm{C}\left(27^{\circ} \mathrm{C}\right.$ to $\left.35^{\circ} \mathrm{C}\right)$, and $12{ }^{\circ} \mathrm{C}\left(23^{\circ} \mathrm{C}\right.$ to $\left.35^{\circ} \mathrm{C}\right)$ significantly increased larval mortality [11], while an increase of $8{ }^{\circ} \mathrm{C}$ significantly lowered adult survival. Another study has investigated the impact of exposure to varying temperature $\left(40^{\circ} \mathrm{C}, 41^{\circ} \mathrm{C}, 42{ }^{\circ} \mathrm{C}, 43^{\circ} \mathrm{C}, 44{ }^{\circ} \mathrm{C}, 45^{\circ} \mathrm{C}, 46^{\circ} \mathrm{C}, 47^{\circ} \mathrm{C}\right.$, or $48^{\circ} \mathrm{C}$ ) on egg hatching of An. gambiae s.s. from Kenya [12], establishing that the survival of eggs was influenced by both temperature and exposure time, with $40^{\circ} \mathrm{C}$ being the upper tolerable temperature, beyond which the rate of egg mortality increased linearly for any given temperature. Significant egg mortalities occurred at temperatures between 42 and $44{ }^{\circ} \mathrm{C}$, less than $20 \%$ of eggs hatched when subjected to $45^{\circ} \mathrm{C}$ for $10 \mathrm{~min}$, and no eggs hatched above $45^{\circ} \mathrm{C}$. With respect to vector control, ambient temperature impacts the efficacy of many public health insecticides e.g., An. gambiae and An. stephensi [13], having a marked effect on the toxicity of the most commonly used insecticides for malaria control, stressing the need to evaluate the efficacy of insecticides/control tools under field conditions [14]. Temperature below the laboratory standard of $26^{\circ} \mathrm{C}$ has been shown to increase the susceptibility of An. stephensi to malathion, with little impact on permethrin susceptibility [15]. An increase in temperature has been established to enhance deltamethrin resistance of a susceptible population of An. arabiensis, while exposure at temperatures both lower and higher than the standard insectary conditions increased mortality in susceptible An. funestus and resistant An. arabiensis [14].

Climate change (increased aridity and drylands) is accelerating evolutionary / adaptive changes in animal species, including insect pests and disease vectors $[2,16]$, potentially selecting evolutionary winners, with the losers, e.g., the species lacking adaptive capacity living near physiological limits and prone to extinction [2]. These adaptive genetic changes occur at chromosomal levels (for example, chromosomal inversions [17]) and/or changes in the allele frequencies of genes involved in thermotolerance and desiccation resistance [16], with increasing periods of thermal stress and drought predicted to produce directional selection for insecticide resistance [2]. 
Paracentric chromosomal inversions are one of the most effective instruments for speciation and local adaptations [17-19], are maintained in spatially and temporally heterogenous environment, segregate along climatic gradients of aridity (https:/ / www3.nd. edu/ nbesansk/Inversions_2018.html, accessed on 12 October 2020), and their frequencies is known to be strongly and significantly correlated with a number of adaptive, phenotypic traits in the Anopheles. The 2La inversion in An. gambiae s.l. strongly correlates with degree of aridity across environmental gradients $[20,21]$, increasing northward from humid to the arid regions in West/Central Africa [20,22], suggesting that the 2La arrangement confers a selective advantage in xeric habitats, while the alternative $2 \mathrm{~L}+{ }^{\mathrm{a}}$ arrangement is more beneficial in the mesic habitats [20]. The An. gambiae s.l. carrying $2 \mathrm{~L}+{ }^{\mathrm{a}}$ allele have been shown to be more susceptible to Plasmodium falciparum infection [23]. An. gambiae s.l. carrying 2La allele are also associated with resistance to desiccation in adults [24,25] and thermal stress in larvae [20,26], were less prone to rest indoors [21], and it was shown that inversion 2La assorts with insecticide resistance, e.g., dieldrin plus fipronil [27].

Several studies have investigated the genetic basis of thermal stress and desiccation resistance. These include measurement of cuticle thickness and cuticular hydrocarbons (CHC) composition in 2La and $2 \mathrm{~L}+{ }^{\mathrm{a}}$ karyotypes, which linked the $2 \mathrm{La}$ arrangement with a thicker cuticle, and differences in the CHC composition associated with lower rate of water loss for the $2 \mathrm{~L}+{ }^{\mathrm{a}}$ karyotype [28]. Comparative gene expression profiling of heat hardened $2 \mathrm{La}$ and $2 \mathrm{~L}+{ }^{\mathrm{a}}$ larvae have established a common and massive induction of a core set of heat shock genes, with the 2La allele preconditioned with a much more aggressive response, with larger numbers of upregulated genes, which are heat responsive and involved in proteolytic degradation and energy metabolism [20]. Fine-scale association mapping of desiccation tolerance within the $2 \mathrm{La}$ and the $2 \mathrm{Rb}$ inversions of $A n$. gambiae s.s. has revealed dozens of significant single nucleotide polymorphisms within both the $2 \mathrm{La}$ and $2 \mathrm{Rb}$ inversions, many of which neighboured genes controlling ion channels or related functions, with transcriptional profiles strongly influenced by karyotype and genes inside rearranged regions overrepresented among those differentially expressed genome-wide [29]. Two of the top-ranking candidate genes discovered in the above recent study have prominent roles in response to environmental stimulus: AGAP006026 encodes an ionotropic glutamate receptor (IR) commonly associated with chemosensation, thermosensation, and hygrosensation [30,31] and AGAP006961 [32] encodes a heat-shock protein gene ( $h s p 90)$.

While several studies have addressed the impact of the 2La inversion on adaptation and insecticide resistance $[17,27]$, little is known of its the impact on pyrethroid (major ingredients in bed nets) resistance in the field population of An. gambiae s.l. Moreover, the few genome-wide transcriptional and association studies carried out to identify the major genes involved in thermotolerance have not investigated the pleiotropic action of the discovered genes on insecticide resistance. This constitutes a knowledge gap hampering insecticides resistance management in field populations of the major malaria vectors, within the context of globally warming world. This study hypothesized that genetic adaptation (e.g., chromosomal inversion) and overexpression of thermotolerance-associated metabolic genes are facilitating thermal acclimation and pyrethroid resistance in the major malaria vector An. gambiae s.l. The study investigated the thermal tolerance breadth of An. gambiae s.l. (An. gambiae s.s. and An. coluzzii) from four sites spanning the northern Guinea savanna and Sudan/sub-Sahel of northern Nigeria, and the role of chromosomal inversion and metabolic resistance genes in tolerance to heat stress and insecticide resistance. Thermotolerance and insecticide resistance were found to be correlated with 2La inversion polymorphism, in heterozygote $\left(2 \mathrm{La} /+^{\mathrm{a}}\right)$ and homozygote $(2 \mathrm{La} / \mathrm{a})$ forms, respectively. qRT-PCR transcriptional profiling of heat-hardened and permethrin-resistant An. coluzzii established the induction/overexpression of a core set of heat shock protein genes previously associated with heat stress, as well as other common heat- and pyrethroidresistance associated genes, including two ionotropic receptors and a trehalose 6-phosphate synthase/phosphatase. 


\section{Materials and Methods}

\subsection{Sampling Sites and Mosquito Populations}

To capture heterogeneities in vector compositions and/or various chromosomal forms of the Anopheles collection was carried out in 4 sites spanning Guinea, Sudan, and subSahel savanna of northern Nigeria (Supplementary Figure S1). Larvae collection was preferred in place of indoor-resting blood fed females to avoid bias from collection of the more endophilic species $[33,34]$. Collections were conducted in the rainy months of July, August, and September, 2019 (mid-July through August, to mid-September) in temporary rain puddles in (i) Bayero University Kano (BUK), situated in Sudan savanna of Kano City (11 $58^{\prime} 17^{\prime \prime} \mathrm{N}, 8^{\circ} 35^{\prime} 9^{\prime \prime}$ E); (ii) Gamjin Bappa, a Sudan savanna village in Karaye, Kano State $\left(11^{\circ} 46^{\prime} 23.6^{\prime \prime} \mathrm{N}, 8^{\circ} 00^{\prime} 29.9^{\prime \prime} \mathrm{E}\right)$; (iii) Pantami, a northern Guinea savanna town located in Gombe State $\left(10^{\circ} 15^{\prime} 50.4^{\prime \prime} \mathrm{N}, 11^{\circ} 09^{\prime} 39.7^{\prime \prime} \mathrm{E}\right)$, and (iv) in irrigation rice paddies in Hadiyau, a village in the sub-Sahel of Auyo, Jigawa State $\left(12^{\circ} 21^{\prime} 38^{\prime \prime}\right.$ N, $9^{\circ} 59^{\prime} 15^{\prime \prime}$ E). Collections were done using classical dipping method [35] and larvae maintained under standard insectarium condition ( $70-80 \%$ relative humidity and $\left.25-27^{\circ} \mathrm{C}\right)$, supplemented with Tetramin ${ }^{\mathrm{TM}}$ Baby fish food, with 12:12 h day/night cycle. Monthly maixmum and minimum ambient temperature (https: / / weatherspark.com/, accessed on 6 June.2021) for the collection sites were $12{ }^{\circ} \mathrm{C}$ and $39^{\circ} \mathrm{C}$, respectively for Kano, $40{ }^{\circ} \mathrm{C}$ and $15^{\circ} \mathrm{C}$ for Auyo, $38^{\circ} \mathrm{C}$ and $12{ }^{\circ} \mathrm{C}$ for Gamjin Bappa, $38^{\circ} \mathrm{C}$ and $14{ }^{\circ} \mathrm{C}$ for Pantami. Extended data for current monthly averages are provided in the Supplementary, File S1.

\subsection{Morphological and Molecular Identification of Mosquito Larvae and Adults}

For every collection, larvae were identified as belonging to the Anopheles gambiae Complex using the morphological keys [36] and maintained as described above. When required larvae were reared to adulthood, and adults maintained as above, with $10 \%$ sucrose solution. A subset of larvae and adults which were used for thermotolerance and insecticide resistance bioassays (see Sections 2.3 and 2.4 below for details) were homogenised and DNA was extracted using LIVAK method [37]. SINE200 PCR [38] was used to identify the larvae and adults to species level.

\subsection{Initial Assessment of Thermotolerance Profile Using Temperature Gradient}

Initial thermotolerance profiling of Anopheles species was conducted by exposing L4 larvae to various temperature gradients $\left(5-46{ }^{\circ} \mathrm{C}\right)$ for $1 \mathrm{~h}$, using a modified protocol of Rocca [26]. This timing was a compromise between the observation of Rocca [26] (120 min which was established as the $\mathrm{LT}_{50}$ at $40^{\circ} \mathrm{C}$ ) and $30 \mathrm{~min}$ at $40^{\circ} \mathrm{C}$ and $43^{\circ} \mathrm{C}$ which was used by Benedict et al. [39]. Larvae from $\mathrm{BUK}$ and Hadiyau were subject to 11 static temperature treatments $\left(5^{\circ} \mathrm{C}, 7{ }^{\circ} \mathrm{C}, 10{ }^{\circ} \mathrm{C}, 15^{\circ} \mathrm{C}, 27^{\circ} \mathrm{C}, 38^{\circ} \mathrm{C}, 42^{\circ} \mathrm{C}, 43^{\circ} \mathrm{C}, 44^{\circ} \mathrm{C}, 45^{\circ} \mathrm{C}\right.$, and $46^{\circ} \mathrm{C}$ ), while those from Gamjin Bappa and Pantami were subjected to 6 temperature regimens: $38{ }^{\circ} \mathrm{C}, 42{ }^{\circ} \mathrm{C}, 43{ }^{\circ} \mathrm{C}, 44^{\circ} \mathrm{C}, 45^{\circ} \mathrm{C}$, and $46^{\circ} \mathrm{C}$ only (due to lack of sample). For the lower temperatures $\left(5^{\circ} \mathrm{C}\right.$ through to $27^{\circ} \mathrm{C}$ ) eight replicates each of 25 larvae were used, while 4 replicates of 25 larvae were used for the higher temperatures $\left(38^{\circ} \mathrm{C}\right.$ through to $46^{\circ} \mathrm{C}$ (due to sample size)). The L4 larvae were placed in $50 \mathrm{~mL}$ glass tubes containing $20 \mathrm{~mL}$ of deionised water, pre-set in a water bath at the experimental temperatures, and allowed to remain for $1 \mathrm{~h}$. Tubes were cooled by transferring into water bath set to $27^{\circ} \mathrm{C}$ and larvae fed with Tetramin food. Number of larvae dead at $24 \mathrm{~h}$ was recorded. In each assay, control groups received same treatment, except that they were maintained at $27^{\circ} \mathrm{C} .4$ replicates of 25 L4 larvae of An. coluzzii (Ngoussou) were exposed to $43^{\circ} \mathrm{C}$ and $44^{\circ} \mathrm{C}$, as well, to assess the thermotolerance status of a known, fully insecticide susceptible colony. The Ngoussou larvae were procured from the LITE, at LSTM, United Kingdom (https:/ /lite.lstmed.ac.uk/, accessed on 9 December 2020).

\subsection{Impact of Heat Hardening on Pyrethroid Resistance}

To investigate the effect of short-term thermal stress [40] on pyrethroid resistance, larvae were pre-exposed for $30 \mathrm{~min}$ at $44^{\circ} \mathrm{C}$, with resting for $2 \mathrm{~h}$ at $27^{\circ} \mathrm{C}$, followed by 
dose-response bioassays with $12.5 \mathrm{mg} / \mathrm{mL}, 25,50$ and $100 \mathrm{mg} / \mathrm{mL}$ of permethrin. For each concentration, 4 replicates of 20-25 larvae were utilised in experiments which were conducted using the WHO procedure [41], with mortalities scored after $24 \mathrm{~h}$. For each of the 4 concentrations, 4 replicates of 20-25 unexposed larvae were used as controls (exposed to respective concentrations of permethrin, but not $44^{\circ} \mathrm{C}$ ). Negative controls were also set for each treatment arms above and were (i) exposed to water containing the solvent (methanol) used to dissolve permethrin, and (ii) maintained in water alone.

To investigate impact of long-term heat-hardening on resistance, sets of the larvae which survived $44{ }^{\circ} \mathrm{C}$ were reared to adulthood and 2-5 day-old females used for WHO tube bioassays with permethrin [42]. Four replicates each of 20-25 females were exposed to impregnated papers containing discriminating doses of permethrin $(0.75 \%)$ for $1 \mathrm{~h}$, transferred to holding tubes and supplied with $10 \%$ sucrose. Mortality was recorded $24 \mathrm{~h}$ after exposure. Two controls were used: (i) 2 replicates of 20-25 adults which survived 44 ${ }^{\circ} \mathrm{C}$ but not exposed to insecticide; and (ii) 2 replicates of $20-25$ adults unexposed to $44{ }^{\circ} \mathrm{C}$ and unexposed to insecticide.

\subsection{Molecular Karyotyping of $2 \mathrm{La}$ and $2 \mathrm{~L}+{ }^{a}$ Inversion Polymorphism}

To establish correlation between thermotolerance and chromosomal inversion larvae were genotyped for the 2La polymorphism. These include $44{ }^{\circ} \mathrm{C}$ survivors (thermotolerant, $T_{R}$ ) and those that died $\left(T_{S}\right)$. Moreover, alive (Insecticide resistant, $I_{R}$ ) and dead $\left(I_{S}\right)$ larvae from $100 \mathrm{mg} / \mathrm{mL}$ permethrin exposure were also genotyped, to correlate insecticide resistance at immature stage with the inversion. In addition, adult females, permethrinalive and permethrin-dead from WHO tube bioassays were also genotyped to establish correlation between pyrethroid resistance and inversion in adult stage. These were adults raised from larvae and they were not exposed to any heat stress (not heat-hardened). All larvae used for genotyping were identified to species level, using the LIVAK DNA extraction protocol, followed by SINE200 PCR (described in Section 2.2 above).

Molecular karyotyping was carried out using PCR $[43,44]$ with primers 23A2 (Universal reverse), 27A2 (for $2 \mathrm{La}$ ) and DPCross5 (for $2 \mathrm{~L}+{ }^{\mathrm{a}}$ ). The PCR mix comprised $11.85 \mu \mathrm{L}$ of $\mathrm{ddH}_{2} 0,5 \mu \mathrm{L}$ of $5 \times$ Buffer, $25 \mathrm{mM} \mathrm{MgCl}_{2}(2 \mu \mathrm{L}), 2.5 \mathrm{mM}$ dNTP mix $(2 \mu \mathrm{L}), 1 \mu \mathrm{M}(1 \mu \mathrm{L})$ each of the above 3 primers and $5 \mathrm{U} / \mu \mathrm{L}$ of GoTaq DNA polymerase (Promega, Wisconsin, USA). Thermocycling conditions were $94{ }^{\circ} \mathrm{C}$ for $2 \mathrm{~min}$, followed by 35 cycles each of $94{ }^{\circ} \mathrm{C}$ for $30 \mathrm{~s}, 60^{\circ} \mathrm{C}$ for $30 \mathrm{~s}$ and $72{ }^{\circ} \mathrm{C}$ for $45 \mathrm{~s}$; and a final extension at $72{ }^{\circ} \mathrm{C}$ for $5 \mathrm{~min}$. PCR amplicons were separated on $2 \%$ agarose gel stained with pEqGREEN and visualised for bands. Product sizes for the 2La and $2 \mathrm{~L}+{ }^{\mathrm{a}}$ arrangements were $492 \mathrm{bp}$ and $207 \mathrm{bp}$, respectively, with heterozygotes having both bands.

\subsection{Transcriptional Profiling of Thermotolerance-Related Genes Using qRT-PCR}

To investigate the potential role of pleiotropic genes on thermotolerance and insecticide resistance, 3-4 day-old females [40] which survived $44^{\circ} \mathrm{C}$ exposure for $1 \mathrm{~h}$ (and allowed to rest for $2 \mathrm{~h} \mathrm{[45]),} \mathrm{those} \mathrm{which} \mathrm{survived} \mathrm{exposure} \mathrm{to} 0.75 \%$ permethrin and unexposed females were used for qRT-PCR, targeting 9 genes previously associated with thermotolerance and/or insecticide resistance [20,31,46-49]. These include 6 heat shock protein genes: [ $h s p 90$ molecular chaperone HtpG (AGAP006959), $h s p 90$ beta (AGAP001424), $h s p 83$ (AGAP006958), $h s p 70$ 1/8 (AGAP004944), hsp90 ATPase activator (AGAP010514) and $h s p 70$ (AGAP004581)]; the trehalose-6-phosphate synthase/phosphatase (TPS 1/2, AGAP008227), and the 2 ionotropic receptor genes, IR21a (AGAP008511) and IR25a (AGAP010272). The primers utilised for the qPCR are provided in the Supplementary Table S1.

The qRT-PCR was carried out using cDNA extracted from $1 \mu \mathrm{g}$ of total RNA from three biological replicates each of the female survivors of heat hardening at $44{ }^{\circ} \mathrm{C}\left(\mathrm{HH}_{\mathrm{R}}\right)$, females unexposed to temperature stress, Control $\left(\mathrm{UNX}_{\mathrm{C}}\right)$, females which survived exposure to $0.75 \%$ permethrin (Insecticide resistant, $I_{R}$ ) and unexposed females from the fully insecticide susceptible laboratory colony, Ngoussou. Protocol followed was as done previously [50], with relative expression level and fold change (FC) of each gene in exposed 
and control females relative to susceptible calculated according to the $2^{-\Delta \Delta C T}$ method, incorporating the PCR efficiency [51], after normalization with the housekeeping genes, ribosomal protein S7, RSP7 (AGAP010592) and elongation factor Tu (AGAP005128).

\subsection{Data Analysis}

R version 3.6.1 (https: / / cran.r-project.org/bin/windows/base/, accessed on 31 January 2021) was utilized to calculate Odds Ratio (epiR package), to establish the relationship between thermotolerance and permethrin resistance with the 2La inversion polymorphism. $\mathrm{LT}_{50}$ and $\mathrm{LC}_{50}$ were calculated and dose-response plots created with generalised linear model (glm) using the MASS package. Plots of results of larval and adult bioassays were made using the GraphPad Prism version 7.02 (GraphPad Inc., La Jolla, CA, USA). Statistical analyses were carried out using a two-tailed Chi-Square test of independence as implemented in GraphPad Prism. The 2La genotyping data from both larvae and adults were also analysed using multiple correspondence analyses with FactoMineR (for analysis) and factoextra (ggplot2-based visualisation) packages of $\mathrm{R}$, to establish a correlation between phenotype and genotype.

\section{Results}

\subsection{Distribution and Composition of Anopheles Gambiae Species}

The larvae found in all the 4 sites, in collections spanning 3 months were An. coluzzii and An. gambiae s.s. However, these species varied in their composition, with An. coluzzii predominant in Auyo and BUK (Table 1, Supplementary File S3) while the two species were on average equally distributed in Gamjin Bappa and Pantami.

Table 1. Distribution and composition of An. gambiae s.l. species.

\begin{tabular}{|c|c|c|c|c|c|c|}
\hline \multirow{2}{*}{ Sampling Site } & \multicolumn{2}{|c|}{$44^{\circ} \mathrm{C}$ (Larvae) } & \multicolumn{2}{|c|}{100 mg/mL Permethrin (Larvae) } & \multicolumn{2}{|c|}{ 0.75\% Permethrin (Adults) } \\
\hline & An. coluzzii & An. gambiae s.s. & An. coluzzii & An. gambiae s.s. & An. coluzzii & An. gambiae s.s. \\
\hline Auyo & 19 & 4 & 14 & 3 & 25 & 3 \\
\hline BUK & 25 & 2 & 18 & 2 & 31 & 1 \\
\hline G/Bappa & 8 & 11 & 10 & 7 & 17 & 11 \\
\hline Pantami & 18 & 12 & 16 & 14 & 10 & 16 \\
\hline Sub-total & $69(70.4 \%)$ & $29(29.6 \%)$ & $58(69 \%)$ & $26(31 \%)$ & $83(72.8 \%)$ & $31(27.2 \%)$ \\
\hline Total & \multicolumn{2}{|r|}{98} & \multicolumn{2}{|r|}{84} & \multicolumn{2}{|c|}{114} \\
\hline
\end{tabular}

\subsection{Thermotolerance Profile and Its Intensity in Anopheles Gambiae s.l. Larvae}

Initial exposure to various temperatures revealed a high thermotolerance, with no mortality in the larvae which were exposed to lower temperature $\left(5-38^{\circ} \mathrm{C}\right.$ ) (Supplementary File S1). For Auyo populations mortalities of $1 \%, 9 \%, 42 \%, 90 \%$, and $99 \%$ were obtained at $42{ }^{\circ} \mathrm{C}$, $43{ }^{\circ} \mathrm{C}, 44^{\circ} \mathrm{C}, 45^{\circ} \mathrm{C}$ and $46^{\circ} \mathrm{C}$ respectively, resulting in estimated $\mathrm{LT}_{50}$ (lethal temperature that killed $50 \%$ of the larvae) of $44.09{ }^{\circ} \mathrm{C}$ (95\% CI: 43.96-44.22) (Figure 1). Similar pattern was observed in the BUK population with no mortality at $42{ }^{\circ} \mathrm{C}$, but mortalities of $3.5 \%$, $38 \%, 90 \%$, and $100 \%$ at $43,44,45$, and $46{ }^{\circ} \mathrm{C}$, respectively ( $\mathrm{LT}_{50}=44.19{ }^{\circ} \mathrm{C}, \mathrm{CI}: 44.08-44.31$ ). No mortality was also obtained at $42{ }^{\circ} \mathrm{C}$ with larvae from Gamjin Bappa, but at $43{ }^{\circ} \mathrm{C}$, $44^{\circ} \mathrm{C}, 44{ }^{\circ} \mathrm{C}$ and $46^{\circ} \mathrm{C}$ mortality increased to $1.25 \%, 47.5 \%, 95 \%$, and $96.25 \%$, respectively $\left(\mathrm{LT}_{50}=44.10^{\circ} \mathrm{C}, \mathrm{CI}: 43.97-44.23\right)$. For Pantami, no mortality was seen at $42{ }^{\circ} \mathrm{C}$ and $43^{\circ} \mathrm{C}$, but at $44^{\circ} \mathrm{C}, 45^{\circ} \mathrm{C}$ and $46^{\circ} \mathrm{C}, 42.5 \%, 66.25 \%$, and $100 \%$ of the larvae died $\left(\mathrm{LT}_{50}=44.44{ }^{\circ} \mathrm{C}\right.$, CI: 44.29-44.58). Highest mortality was obtained from the Ngoussou, $37 \%$ for $43^{\circ} \mathrm{C}$ and $100 \%$ for $44{ }^{\circ} \mathrm{C}$, suggesting that the laboratory colony is more thermo-susceptible than the field populations. 

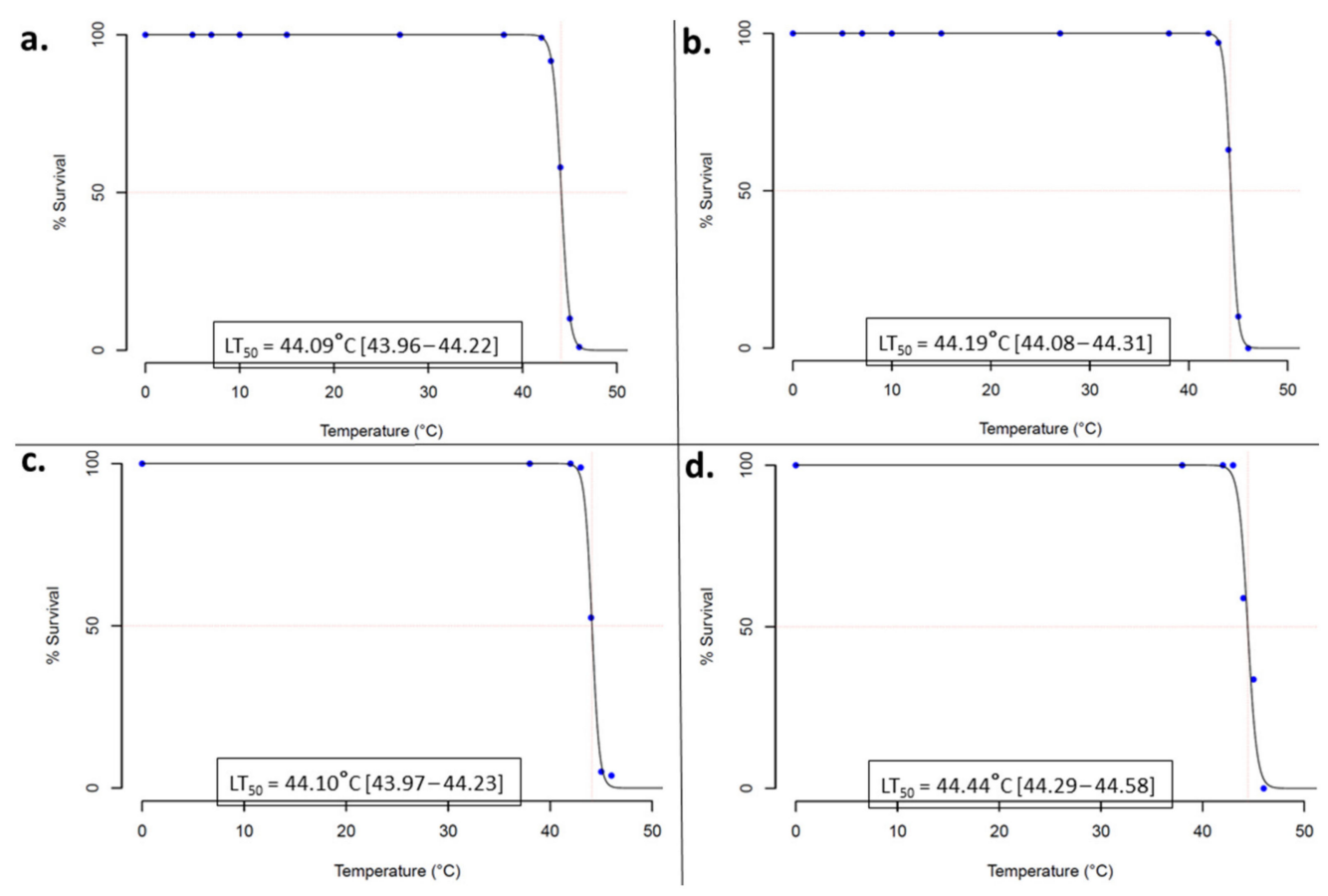

Figure 1. Thermotolerance profile of various populations of Anopheles gambiae s.l. larvae. Doseresponse (temperature-course) bioassays for (a). Auyo, (b). BUK, (c). Gamjin Bappa and (d). Pantami. $\mathrm{LT}_{50}$, the temperature that killed $50 \%$ of the larvae are given inside rectangular inset with $95 \%$ confidence intervals in square brackets.

\subsection{Impact of Heat Hardening on Pyrethroid Resistance}

Bioassay using the $44^{\circ} \mathrm{C}$ heat-hardened larvae revealed a high permethrin resistance in all the four populations, with mortalities of $<50 \%$ on average for even $100 \mathrm{mg} / \mathrm{mL}$ concentration (Figure 2, Supplementary File S2). Mortalities followed dose-dependent pattern with lowest obtained from $12.5 \mathrm{mg} / \mathrm{mL}$ permethrin. Significant differences in the mortalities were observed between the experimental and control larvae, for BUK $\left(50 \mathrm{mg} / \mathrm{mL}, \chi^{2}=3.908, p<0.05\right.$ and $\left.12.5 \mathrm{mg} / \mathrm{mL}, \chi^{2}=6.25, p<0.01\right)$ and for Pantami $\left(12.5 \mathrm{mg} / \mathrm{mL}, \chi^{2}=5.76, p<0.01\right)$ (Figure $2 \mathrm{~b}, \mathrm{~d}$, respectively). However, sample sizes ( $\sim 80$ larvae for this concentration) from each of these two sites could have impacted this outcome. The $\mathrm{LC}_{50}$ (concentration of permethrin that killed $50 \%$ of the larvae) was high (in ranges of 102-184 mg/mL), with Gamjin Bappa exhibiting the highest $\mathrm{LC}_{50}$, and specifically the experimental larvae of this population exhibiting higher $\mathrm{LC}_{50}$ compared with the control.

Adult bioassay with permethrin revealed high resistance, with mortalities of less than $20 \%$ in both experimental and control cohorts. However, differences in mortalities were observed between the experimental cohorts (raised from larvae which survived exposure at $44^{\circ} \mathrm{C}$ ) and control (Figure 3). For example, significantly lower mortality $(3.00 \% \pm 1.20$, $\left.\chi^{2}=5.83, p<0.01\right)$ was obtained from Auyo experimental cohort compared with control $(12.00 \% \pm 4.65)$. For the other three sites, mortalities were not significantly different between experimental and control, though in all cases it was higher in the control. 

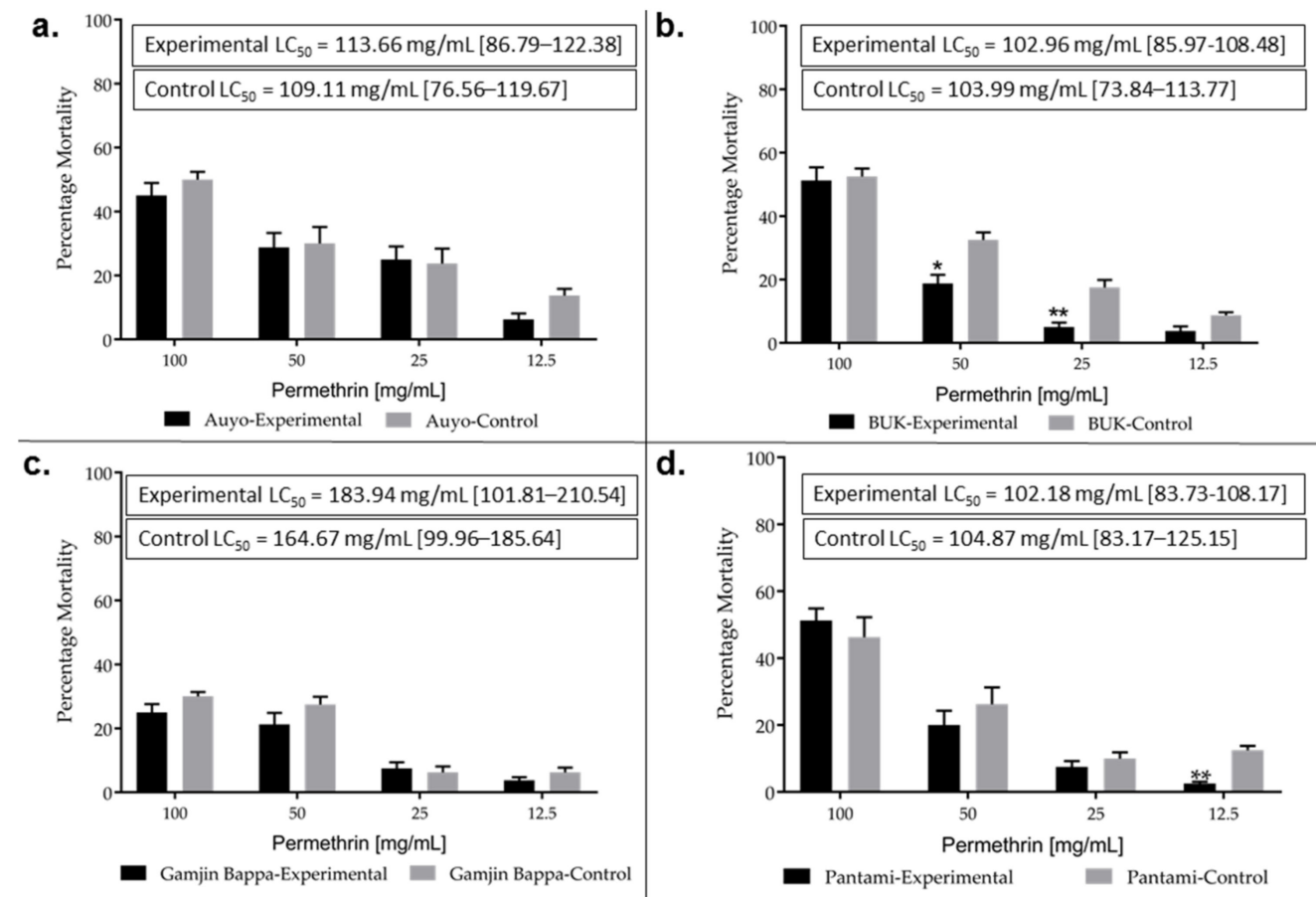

Figure 2. Resistance profiles of Anopheles gambiae s.l. larvae. Results of WHO larval bioassay with permethrin, for (a). Auyo, (b). BUK, (c). Gamjin Bappa and (d). Pantami. * and ** = statistically significant at $p<0.05$ and $p<0.01$, respectively from two tailed $\chi^{2}$ square test of independence. LC $_{50}$ for experimental and control larvae for each of the 4 sites are provided in rectangular inset with $95 \%$ confidence limits.

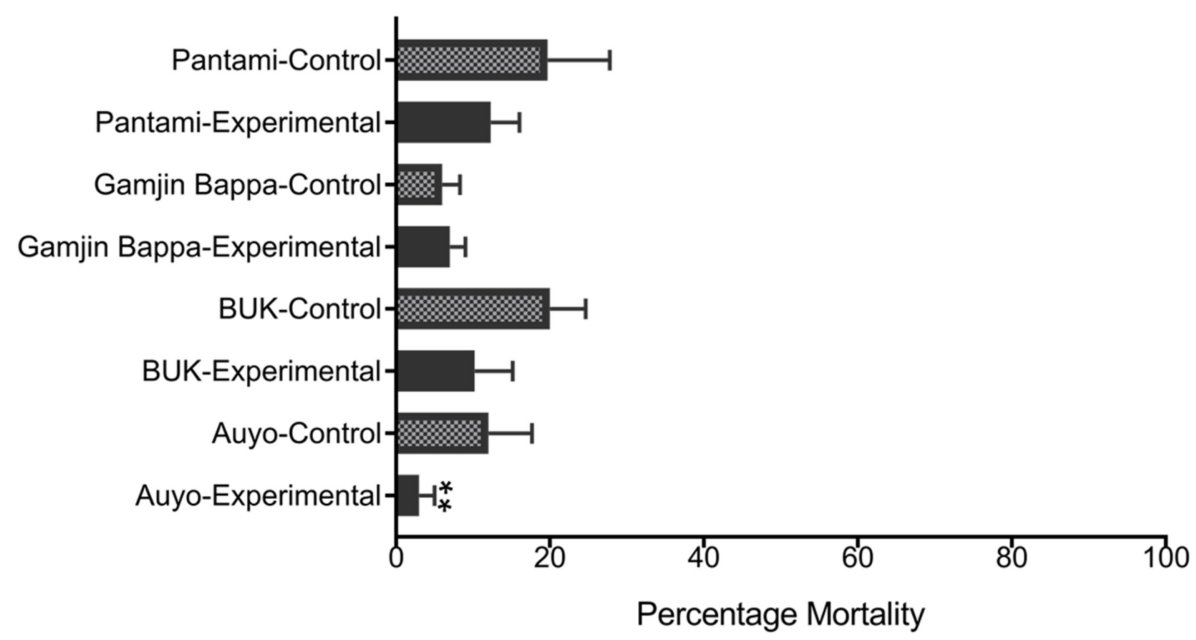

Figure 3. Result of susceptibility bioassay using heat-hardened and control adult An. gambiae s.l. females. WHO bioassays with $0.75 \%$ permethrin. ${ }^{* *}=$ significantly different from the control at $p<0.01$.

\subsection{Role of 2La Chromosomal Inversion on Thermotolerance and Pyrethroid Resistance}

To investigate the role of chromosomal inversion on thermal stress and permethrin resistance, larvae used for thermotolerance tests (alive and dead from $44{ }^{\circ} \mathrm{C}$ exposure), and those exposed to $100 \mathrm{mg} / \mathrm{mL}$ permethrin were karyotyped for the 2La inversion (Supplementary Figures S2 and S3, respectively for agarose gel pictures). Moreover, adults exposed to $0.75 \%$ permethrin (both alive and dead) were genotyped for the inversion (Supplementary Figure S4). 
For BUK larvae exposed to $44^{\circ} \mathrm{C}$, significant association (odds ratio, $\mathrm{OR}=7.2(1.08-4.79)$, $\left.\left.\chi^{2}=4.68, p<0.03\right)\right)$ was observed between survival and heterozygosity $\left(2 \mathrm{La} /+^{\mathrm{a}}\right.$ arrangement) compared with $2 \mathrm{~L}+{ }^{\mathrm{a}} /+^{\mathrm{a}}$ form (Supplementary Table S2). For the other three sites, the differences were not significant, as well as for the combined data. Overall, from the larvae successfully genotyped, $55(56.12 \%)$ were alive and $43(43.88)$ dead, and the distribution of $2 \mathrm{La} / \mathrm{a}, 2 \mathrm{La} /+^{\mathrm{a}}$ and $2 \mathrm{~L}+{ }^{\mathrm{a}} /+^{\mathrm{a}}$ were $16(13.33 \%), 36(36.73 \%)$ and $46(46.94 \%)$, respectively. Multiple correspondence analysis (MCA) identified variables that explained highest variability in the data. The eigenvalues (which determine the number of variables to consider) revealed dimensions $1-5$ as constituting $81.8 \%$ in the variability in the data (Scree plot in Supplementary Figure S5a showed the contribution of the dimensions, and S5b and S5c describe the variable contributions and cos2 (inertia of the variables), respectively). Variable categories with similar profiles clustered together on the factor map, for example, Pantami, Gamjin Bappa, and An. gambiae s.s. clustered on the positive quadrant of dimension one consistent with the high percentage of this species in the above two sites (Figure 4). The alive and $2 \mathrm{La} /+^{\mathrm{a}}$ clustered together on the negative quadrant of dimension 2 supporting the significant correlation observed between $2 \mathrm{La} /+^{\mathrm{a}}$ and heat stress survival. Auyo, BUK, An. coluzzii and $2 \mathrm{~L}+{ }^{\mathrm{a}} /+^{\mathrm{a}}$ clustered together since this species is the dominant one in these two sites, and since $2 \mathrm{~L}+{ }^{\mathrm{a}} /+^{\mathrm{a}}$ arrangement is not linked to thermal and desiccation tolerance, an alternative mechanism is possibly contributing to the thermotolerance in An. coluzzii (note that the distance between alive and An. coluzzii indicates their similarity compared to the variable dead, which cluster with $2 \mathrm{La} / \mathrm{a}$ arrangement). The variables $A n$. coluzzii and An. gambiae s.s. which clustered on the opposite side of dimension 2 pole contributed the most to the inertia of the factor map, followed by $2 \mathrm{La} /+^{\mathrm{a}}$ inversion arrangement (Supplementary Figure S6).

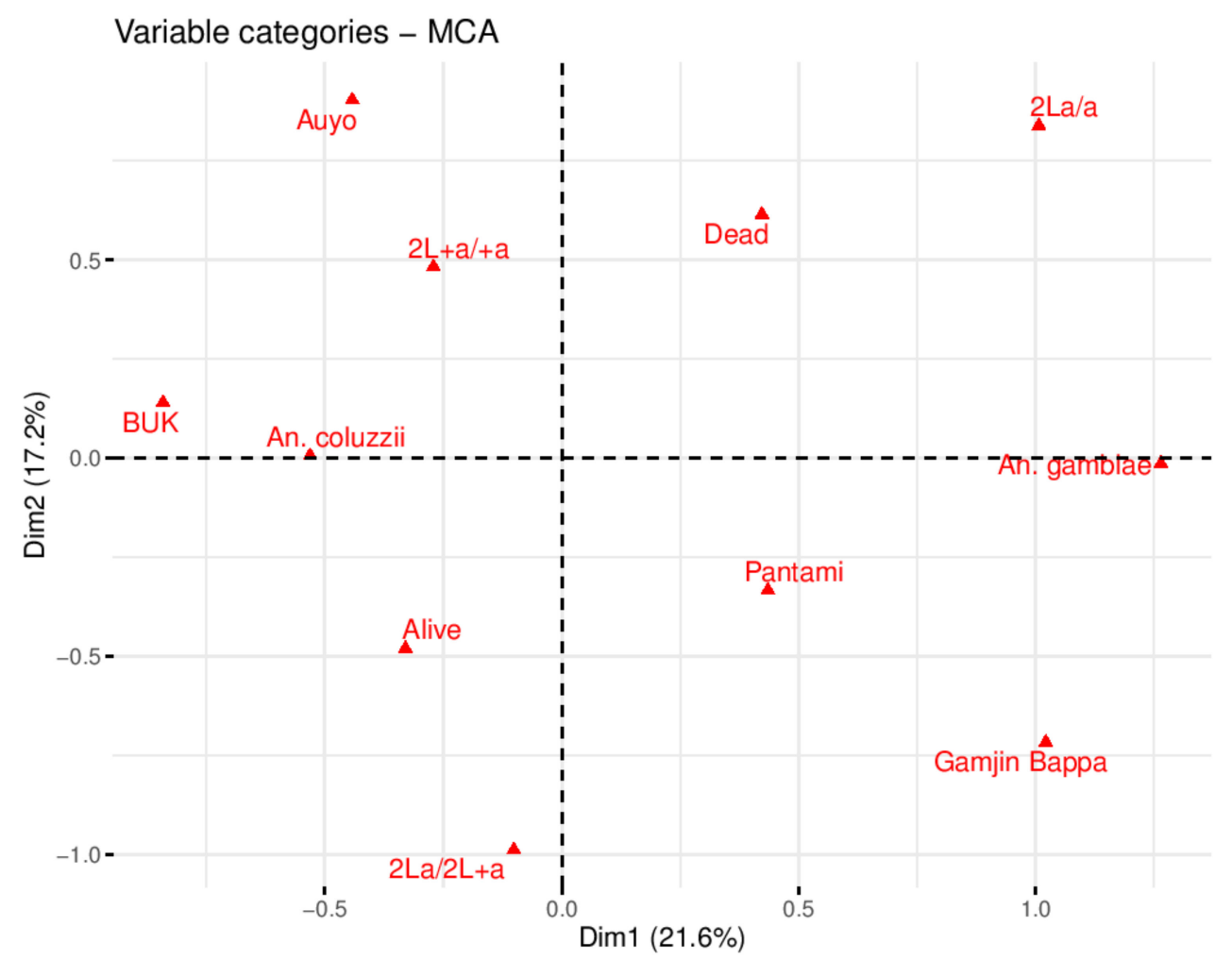

Figure 4. MCA plot of variables from larvae exposed to $44{ }^{\circ} \mathrm{C}$ heat stress. Asymmetric/biplot variables on dimensions 1 and 2. Variable categories with similar profiles are grouped together. Negatively correlated variable categories are positioned on the opposite side of the plot origin (opposed quadrants). Variables cluster close to the pole, positive or negative of each dimension indicating how important is their contribution to the dimension. 
For larval bioassay with permethrin, no significant difference in distribution of 2La inversion was observed between alive and dead in each site and for the combined data from all the four sites. From the larvae successfully genotyped, 41 were resistant $(48.8 \%$ alive) and 43 were dead $(51.2 \%)$, and the distribution of $2 \mathrm{La} / \mathrm{a}, 2 \mathrm{La} /+^{\mathrm{a}}$, and $2 \mathrm{~L}+{ }^{\mathrm{a}} /+^{\mathrm{a}}$ was $15(17.85 \%), 32(38.09 \%)$, and $37(44.04 \%)$, respectively.

In contrast, for the adult bioassays there was low frequency of $2 \mathrm{La} / \mathrm{a}$ arrangement among the dead females, with none in BUK and Gamjin Bappa. A significant association $\left(\mathrm{OR}=5.02(1.48-6.93), \chi^{2}=7.45, p=0.01\right)$ was observed between survival and 2La/a homozygosity when alive and dead females were compared, for all data. Overall, from the adults successfully genotyped, $83(72.8 \%)$ were alive and 31 were dead (overall percentage mortality $=27.2)$, and the distribution of $2 \mathrm{La} / \mathrm{a}, 2 \mathrm{La} /+^{\mathrm{a}}$, and $2 \mathrm{~L}+{ }^{\mathrm{a}} /+^{\mathrm{a}}$ was $25(21.92 \%)$, $42(36.84 \%)$, and $47(41.23 \%)$, respectively. The eigenvalues revealed dimensions $1-5$ as contributing $84.8 \%$ in the variability of the data (Scree plot in Supplementary Figure S5d shows contribution of dimensions, and S5e and S5f demonstrated the variable contributions and $\cos 2$ (inertia of the variables), respectively). Variables $2 \mathrm{~L}+{ }^{\mathrm{a}} /+^{\mathrm{a}}$ and dead clustered together (Figure 5); Auyo, BUK, An. coluzzii, and $2 \mathrm{La} /+^{\mathrm{a}}$ clustered together, consistent with the high percentage of this species in these sites. Alive and 2La/a were most close in the right quadrant of dimension 1, supporting the observation of a significant association between permethrin survival and the inversion in homozygous state. As in the thermotolerance bioassay biplot, the variable category species (An. coluzzii and An. gambiae s.s.) contributed the most inertia for the dimensions (Supplementary Figure S7).

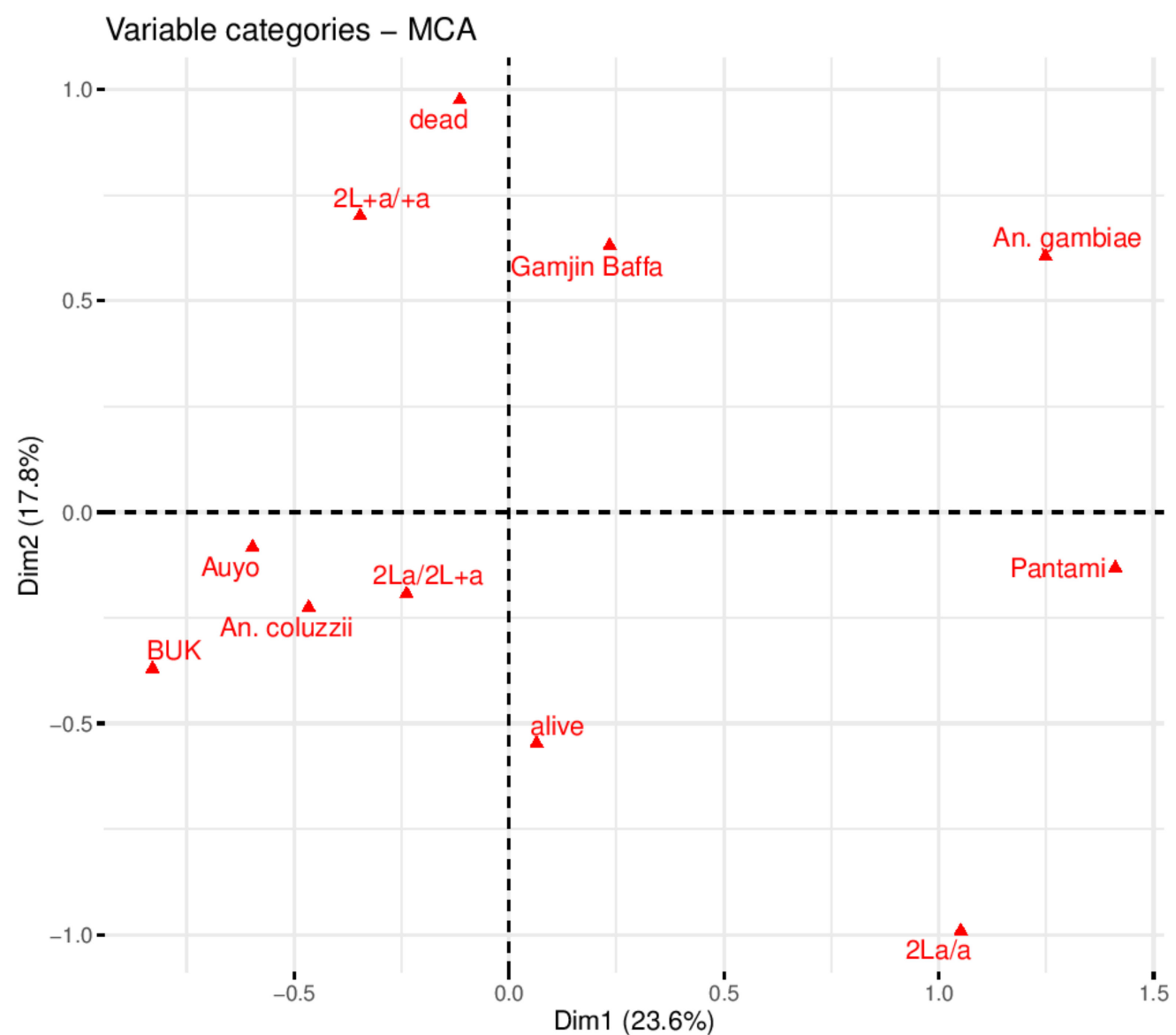

Figure 5. MCA plot of variables from female adults exposed to permethrin. Asymmetric/biplot of variables on dimensions 1 and 2. Variable categories with similar profiles are grouped together. Negatively correlated variable categories are positioned on the opposite side of the plot origin (opposed quadrants). Variables cluster close to the pole, positive or negative of each dimension indicating how important is their contribution to the dimension. 


\subsection{Impact of Heat Hardening on Expression Profile of Thermotolerance- and Resistance-Associated Genes}

Comparative profiling of expression of nine genes associated with thermotolerance and/or resistance revealed the common metabolic genes differentially expressed with respect to thermal stress and pyrethroid exposure. Three major heat shock protein genes were highly overexpressed in heat-hardened mosquitoes and to some level in permethrin resistant females (Figure 6). The most overexpressed gene was hsp70 (AGAP004581), massively induced in heat hardened (HHR) females, with a fold change (FC) of 2468, FC of 4.64 in permethrin-resistant females (IR), and FC of 1.08 in unexposed females (UNXC), all compared to Ngoussou. This was followed by hsp83 (AGAP006958) with FC of 125.2, 5.9 , and 2.7 in HHR, UNXC, and IR, respectively. The third most overexpressed gene was the hsp90 hptG (AGAP006959) which was also induced in HHR and IR, with FC of 51.7 and 8.3, respectively. The TPS-1/2 (AGAP0008227) was also induced, with the highest FC of 4.42 in HHR, and comparable expression of 2.59 and 2.56 in the IR and UNXC, respectively, highlighting its constitutive overexpression in the field populations. The two ionotropic receptor genes were also differentially expressed with IR-25a (AGAP010272) having the higher FC of 4.8 in IR, followed by HHR (FC = 2.71) and UNX (1.59). The IR-21a (AGAP008511) was only induced significantly in the permethrin resistant (IR) females $(\mathrm{FC}=2.6)$, suggesting the preeminent role of this gene in insecticide resistance.

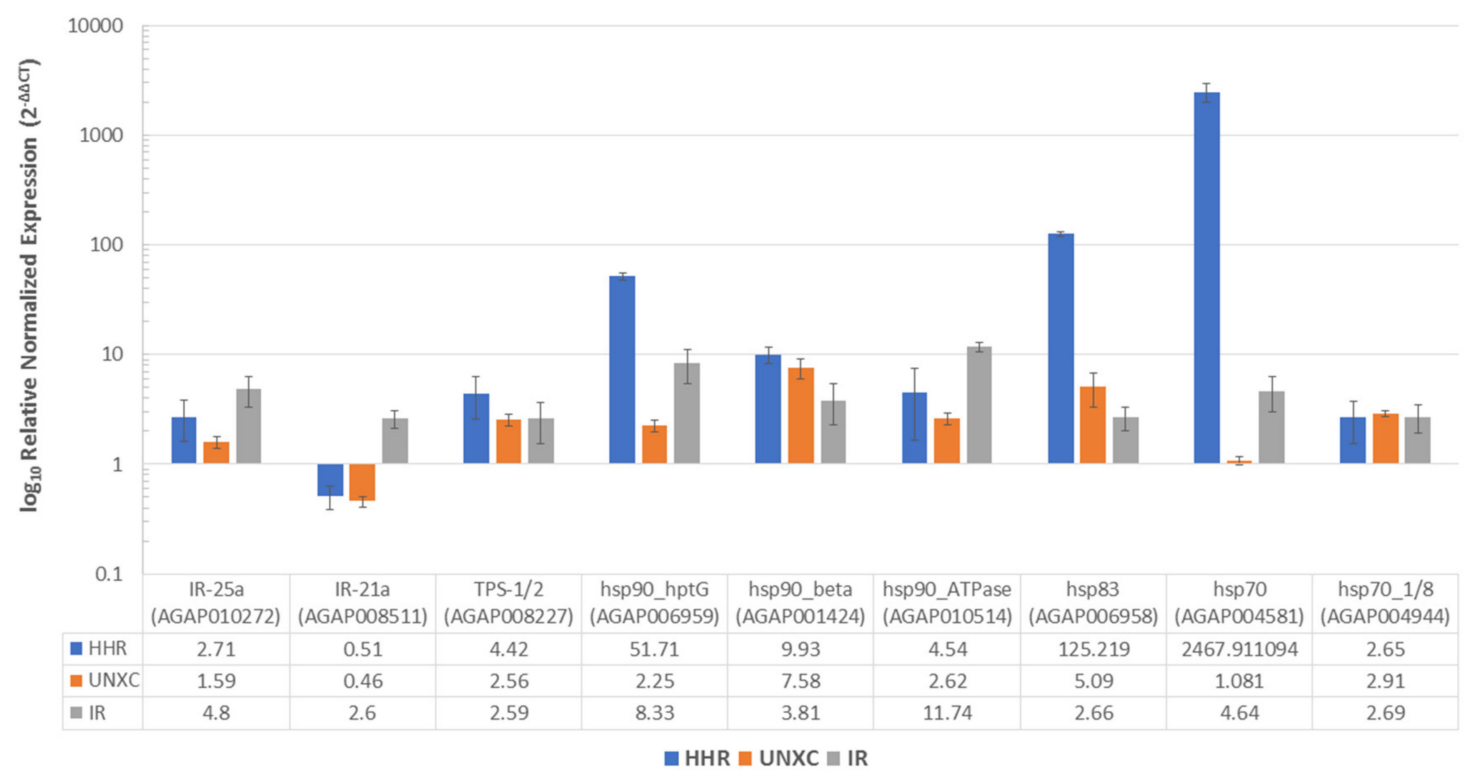

Figure 6. Differential expression profiles of 9 genes putatively linked with thermotolerance and/or insecticide resistance. Comparison of heat-hardened adult, female An. coluzzii (HHR), Unexposed females (UNXC) and adult survivors of permethrin exposure (IR) to the fully susceptible laboratory colony, Ngoussou. Fold-changes were obtained from the average of 3 independent biological replicates, each of 3 technical replicates. Error bars represent standard deviation. Fold change data table shown below the $\mathrm{x}$ axis. Y-axis log to base 10 transformed due to the very high overexpression of $h s p 70$ in HHR females.

\section{Discussion}

Under the projection of the future warmed world, mosquito species equipped with genetic and/or plastic advantages may better survive harsh conditions of tropical Africa, particularly the xeric, arid Sahel in the West Africa. Chromosomal inversion polymorphism (which promote ecological flexibility and enable exploitation of heterogeneous environments) and/or a suite of pleiotropic genes involved in thermosensation/thermoregulation, hygrosensation and chemosensation conferring adaptive benefit in arid region, as well as protection from insecticide-based vector control measures may select for a DVS in the future. Understanding the role of inversion polymorphism and the genes enhancing life traits 
in the major malaria vectors will help in reducing malaria risk and promote evidence-based resistance management.

\subsection{Evidence of Sympatry between An. coluzzii and An. gambiae s.s. in Northern Nigeria}

In this study the two malaria vectors, An. coluzzii and An. gambiae s.s. were the only species found in four sites spanning northern-Guinea savannah, Sudan savanna and sub-Sahel of northern Nigeria. Despite the sympatric existence of these sibling species no An. coluzzii/An. gambiae s.s. hybrids were obtained strengthening the evidence of positive assortative mating within these molecular forms [22]. However, in line with our recent findings across Sudan/Sahel [33-35,52,53], An. coluzzii was the major vector found in all the sites, even though An. gambiae s.s. was also in high proportion in the less xeric Gamjin Bappa and Pantami. Previous observations have described An. arabiensis as the dominant vector species (DVS) in the northern-most drier/arid environments of Sudan Savannah and Sahel, extending along increasing latitudinal cline, for example, in Niger, Nigeria and Cameroon [22,54-56]. However, within the last few years, the pervasive An. coluzzii has become the DVS in the Sahel of southern Niger and central Chad, and in the sub-Sahel of northern Nigeria and Cameroon. This is probably due to this species higher exploitation of breeding sites associated with anthropogenic activities and behavioural plasticity to avoid predators [57], and surviving a long dry season in situ/aestivation, which allows it to predominate and become the primary force of malaria transmission [58,59]. Moreover, photoperiod and lower nightly temperature have been shown to significantly increase the longevity of the An. coluzzii-a mechanism which will allow it to diapause in the dry season and re-establish first in the early rainy season [60].

\subsection{Evidence of High Intensity Thermal Stress Tolerance in Anopheles gambiae s.l. Larvae}

The larvae used in this study exhibited a broad thermal breadth with no mortalities between $5-38{ }^{\circ} \mathrm{C}$. The high thermotolerance observed in these populations $\left(\mathrm{LT}_{50}\right.$ of $\sim 44^{\circ} \mathrm{C}$ ) suggests that the larvae are equipped with mechanisms to survive in xeric conditions. A study on the thermal tolerance/egg hatching ability of An. gambiae s.s. has established upper tolerable temperature of $40{ }^{\circ} \mathrm{C}$, with mortalities increasing linearly with time above this temperature, reaching $100 \%$ at $44{ }^{\circ} \mathrm{C}$ for $30 \mathrm{~min}$, and with no egg hatching for $10 \mathrm{~min}$ exposure at $45^{\circ} \mathrm{C}$ [12]. This pattern is similar to the observation of our study. Protein denaturation/degradation has been shown to occur in temperatures between 42 and $45^{\circ} \mathrm{C}[12,61]$. Another study carried out two decades ago have utilised ranges of temperature $\left(37-44.5^{\circ} \mathrm{C}\right)$ to establish in An. albimanus larval mortality occurring in a very narrow temperature range, between 40 and $43{ }^{\circ} \mathrm{C}$ [39], with $100 \%$ of larvae dead at 44.5 ${ }^{\circ} \mathrm{C}$. The findings of the present study closely agree with the observations of the above study. Another study on An. gambiae s.s. have used $40{ }^{\circ} \mathrm{C}$ to estimate relationship between exposure time and survival rate, showing that mortality increased linearly with time [26]. Moreover, increased temperatures $\left(23-35^{\circ} \mathrm{C}\right.$ for rearing to adulthood) have been shown to decrease An. gambiae larvae survival and reduce adult longevity [10].

\subsection{Heat Hardening Enhances Insecticides Tolerance in Larvae and Adult Anopheles Gambiae s.l.}

Temperature has been shown to be a critical factor modulating insecticide resistance. In this study short-term exposure at $44{ }^{\circ} \mathrm{C}$ enhanced permethrin resistance in both larvae and adults An. gambiae s.l. A previous study has reported augmentation of pyrethroid resistance in both resistant and susceptible populations of adult $A n$. arabiensis exposed to $37^{\circ} \mathrm{C}$ and $39^{\circ} \mathrm{C}[40]$, with the insecticide resistant population living longer at higher temperature. In contrast, another recent study has found that increasing temperature enhanced the deltamethrin resistance of the susceptible $A n$. arabiensis populations while exposure at temperatures both lower and higher than standard insectary conditions increased mortality in resistant population of this species [14]. Other studies have shown a positive temperature coefficient on insecticides, e.g., in An. gambiae and An. stephensi [13], and in other nonAnopheles insects [62]. 


\subsection{La Chromosomal Inversion Enhances Thermotolerance and Permethrin Resistance}

Chromosomal inversion is known to segregate along climatic gradient of aridity, increasing in frequency along geographical clines, from mesic to xeric environments of the arid regions [21,24]. In this study, frequency of the $2 \mathrm{La}$ arrangement was found to be on average between $50 \%$ in the larvae karyotyped and $58 \%$ in the adults, with the heterozygote arrangement $\left(2 \mathrm{La} /+^{\mathrm{a}}\right)$ on average twice the frequency of homozygote form. The 2La homozygotes have been shown to be absent in cyclodiene resistant populations of An. gambiae s.s. from northern Nigeria [27]. Moreover, the frequency of 2La inversion in natural populations of An. gambiae from Kenya has been shown to decrease from $100 \%$ to $17 \%$ in less than a decade due to pressure from increased ownership and use of insecticide treated nets which could select against house entering or indoor resting [63], reversing the selection of 2La chromosomal form.

This study established a correlation between 2La inversion polymorphism (heterozygote form, $2 \mathrm{La} /+^{\mathrm{a}}$ only) and thermotolerance in a single population out of the four studied. However, further genotyping needs to be carried out with larger sample to confirm this pattern. The finding of high frequency of heterozygote arrangement $2 \mathrm{La} /+^{\mathrm{a}}$ suggests its possible association with phenotypic advantage, keeping adaptive alleles in heterozygote state, to avoid the otherwise highly deleterious homozygote alleles [64]. Adult An. gambiae s.s. carrying $2 \mathrm{La}$ allele are known to be desiccation resistant $[24,25]$ and heat-hardened larvae carrying the arrangement exhibited thermal stress tolerance higher than alternative arrangement $[20,26]$.

Considering the data from all the four sites, the $2 \mathrm{La} / \mathrm{a}$ arrangement was also found associated with permethrin resistance in adults, when compared to $2 \mathrm{~L}+{ }^{\mathrm{a}} /+^{\mathrm{a}}$. Inversion in chromosome 2 have been shown to modulate insecticide resistance in Anopheles mosquitoes. For example, $2 \mathrm{Rb}$ inversion was associated with DDT resistance in An. arabiensis from Ethiopia [65] and An. gambiae from northern Nigeria [66], and 2La/ $+{ }^{\mathrm{a}}$ heterozygote $A n$. gambiae has been shown to be resistant to cyclodienes [27]. The link between inversions in chromosome 2 and insecticide resistance is not surprising since many detoxification genes are located within the inverted regions in this chromosome, e.g., the voltage-gated sodium channel gene, CYP6P3 and CYP6P4 which are located within the 2La and 2Rc inversions, respectively [67].

\subsection{Common Metabolic Resistance Genes Are Associated with Thermotolerance and Permethrin Resistance}

Short term heat-hardening has been shown to benefit Drosophila $[68,69]$ by inducing heat shock proteins [45] which act as molecular chaperones for denatured proteins from heat stress [70]. In this study, short-term heat-hardening induced overexpression of several heat shock protein genes, most especially the $h s p 70$ (AGAP004581). This inducible gene has been implicated in thermal acclimation in Drosophila, with level of its expression increasing with time of exposure [45] and has been known to be involved in ameliorating the stress of blood-feeding, which is associated with elevated body temperature in Aedes aegypti [47]. The fact that this chaperone protein is also overexpressed in permethrinresistant females suggest its pleiotropic effect toward insecticide resistance. Three other hsp genes found to be overexpressed in both heat-hardened and permethrin-resistant cohort are heat shock protein genes $h s p 90$ (AGAP006959, hptG), AGAP006958 (part of the three tandemly arranged $h s p 83$ genes) and $h s p 90$ co-chaperone Aha1. These three hsp genes together with the $h s p 70$ were among the core set of hsp genes involved in a common and immediate response to thermal stress in An. gambiae populations [20]. The other two hsp genes found to be overexpressed in the natural populations compared with Ngoussou were $h s p 90 \_$beta and $h s p 701 / 8$.

Trehalose (synthesized by TPS 1/2) contribute to the maintenance of warm temperature, a condition needed for survival of Anopheles [46,71] and is known to promote longevity, fecundity and cold tolerance in insects [49], as well as stabilizing proteins during thermal stress [72]. TPS 1/2 was also found to be overexpressed in heat-hardened, unexposed, and 
permethrin-resistant females, compared with Ngoussou, with the highest expression in heat-hardened females. Ionotrophic receptors have been shown to be a requirement for humidity sensing (hygrosensation), with IR25a and IR21a known to mediate both humidity and temperature preference in the fruit fly, Drosophila melanogaster [31,48], in addition to IR21a driving heat seeking and heat-stimulated blood feeding in An. gambiae [48]. The level of expression of IR25a was found to be higher than IR21a, with the highest expression in permethrin-resistant individuals, followed by heat-hardened cohorts. This suggests a possible role of these glutamate receptors in thermotolerance and insecticide resistance.

Amongst the genes found to be induced/overexpressed, hsp70 (AGAP004581), AGAP001424 (hsp90), AGAP004944 (hsp70 1/8), TPS 1/2, and IR25a are among the set of genes significantly upregulated from a recent RNAseq-based genome-wide transcriptional analysis in pyrethroid resistant populations of An. coluzzii from the Sahel (in preparation). Additional work needs to be done to fully elucidate the molecular basis of thermotolerance and its link to insecticide resistance. For example, the role of heat shock proteins in chaperoning the major insecticide resistance genes (using functional genomics and protein biochemistry) can be exploited as Achille's heels to target insecticide resistant mosquitoes.

\section{Conclusions}

Temperature critically influences the life traits of insects, and its increase lead to more generations per year, increase species range, and favour the survival of insecticide resistant Anopheles vectors, impacting epidemiological effects in terms of malaria transmission. This study has established sympatric existence of the major malaria vectors An. coluzzii and An. gambiae s.s. in northern Nigeria and shown that the species are highly thermotolerant and highly resistant to permethrin, in both immature and adult stage. The preliminary findings of this study suggest the role of 2La chromosomal inversion in both thermotolerance (in larvae) and permethrin resistance (in adults). Common metabolic resistance genes are potentially involved in thermotolerance and permethrin resistance in adult An. coluzzii, the DVS in the localities sampled. These findings highlight the challenges associated with malaria vector control and provide a glimpse of the mechanisms that mosquitoes are likely to use to adapt to future temperature extremes and the sustained usage of insecticide-based malaria control tools.

Supplementary Materials: The following are available on https:/ / www.mdpi.com/article/10.3390/ biology10060518/s1, Figure S1: Map of the four sampling sites in northern Nigeria. Red star for BUK and Gamjin Bappa (Kano State), Auyo (Jigawa State) and Pantami (Gombe State); Figure S2: Agarose gel of 2La karyotyping using larvae from heat stress bioassay. a. top panel is for Auyo alive (lanes 1-13) while the lower panel is Auyo dead (lanes 1-9); b. BUK alive 1-13; c. BUK dead, 1-15; d. Gamjin Bappa alive (1-11) and dead (12 and 13); and e. Gamjin Bappa dead (1-3), Pantami alive (4-19) and Pantami dead (20-33); Figure S3: Agarose gel of 2La karyotyping using larvae from permethrin bioassay. a. BUK alive (lanes 1-9), BUK dead (10-20), Gamjin Bappa alive (21-26) and Gamjin Bappa dead (27-37); b. Pantami alive (1-15) and Pantami dead (16-30); c. Auyo alive 1-11 and Auyo dead 1217. Number 18 not identified from species identification; Figure S4: Agarose gel of 2La karyotyping using adult females from permethrin bioassay. a. Auyo alive (lanes 1-16), Auyo dead (17-28), BUK alive (29-31); b. BUK alive (1-19), BUK dead (20-29), Pantami alive (30); c. Pantami alive (1-16), Pantami dead (17-26), Gamjin Bappa dead (27-35); and d. Gamjin Bappa alive (1-19); Figure S5: Relative contribution of variables on the factor map. a., b. and c. are Scree plot of the 7 dimensions, $\cos 2$ and variables contributions, respectively for dimensions 1-5, from heat stress bioassay. Highest values reflect highest contribution to the dimension (variability); d., e. and f. are Scree plot of the 7 dimensions, $\cos 2$ and variables contributions, respectively for dimensions 1-5, from adult bioassays with permethrin; Figure S6: $\cos 2$ of variables with An. coluzzii and An. gambiae s.s. (An. gambiae in the plot) exhibiting the highest inertia/contribution; Figure S7: $\cos 2$ of the variables with An. coluzzii and An. gambiae s.s. (An. gambiae in the plot) exhibiting the highest inertia/contribution; Table S1: Primers used for qRT-PCR; Table S2: Summary of the 2La inversion distribution in larvae and adult Anopheles mosquitoes ; File S1: Results-Temperature-Gradient-and-LT50s, File S2: Results-Larval-andAdult-Bioassays-Rowdata, File S3: Results-Inversion-Polymorophism-Genotyping-Rowdata. 
Author Contributions: Conceptualization, S.S.I. and C.S.W.; methodology, M.M.M., S.S.I. and A.M.; validation, S.S.I. and C.S.W.; formal analysis, S.S.I.; investigation, M.M.M. and S.S.I.; resources, S.S.I. and C.S.W.; data curation, S.S.I.; writing-original draft preparation, S.S.I.; writing-review and editing, S.S.I., A.M. and M.M.M.; visualization, S.S.I.; supervision, S.S.I.; project administration, S.S.I.; funding acquisition, S.S.I. All authors have read and agreed to the published version of the manuscript.

Funding: This research was funded by Wellcome Trust (https://wellcome.ac.uk/, accessed on 31 January 2021), grant number WT201918/Z/16/Z and the APC was covered by the Wellcome Trust.

Institutional Review Board Statement: Not applicable.

Informed Consent Statement: Not applicable.

Data Availability Statement: The raw data generated from this study are available in the supplementary files.

Conflicts of Interest: The authors declare no conflict of interest. No funder has a role in the design of the study; in the collection, analyses, or interpretation of data; in the writing of the manuscript, or in the decision to publish the results.

\section{References}

1. Hodgson, J.A.; Thomas, C.D.; Oliver, T.H.; Anderson, B.J.; Brereton, T.M.; Crone, E.E. Predicting insect phenology across space and time. Glob. Chang. Biol. 2011, 17, 1289-1300. [CrossRef]

2. Hoffmann, A.A.; Sgro, C. Climate change and evolutionary adaptation. Nat. Cell Biol. 2011, 470, 479-485. [CrossRef]

3. Ren, Z.; Wang, D.; Ma, A.; Hwang, J.; Bennett, A.; Sturrock, H.; Fan, J.; Zhang, W.; Yang, D.; Feng, X.; et al. Predicting malaria vector distribution under climate change scenarios in China: Challenges for malaria elimination. Sci. Rep. 2016, 6, 20604. [CrossRef] [PubMed]

4. Ryan, S.J.; Lippi, C.; Zermoglio, F. Shifting transmission risk for malaria in Africa with climate change: A framework for planning and intervention. Malar. J. 2020, 19, 1-14. [CrossRef] [PubMed]

5. Semakula, H.M.; Song, G.; Achuu, S.P.; Shen, M.; Chen, J.; Mukwaya, P.I.; Oulu, M.; Mwendwa, P.M.; Abalo, J.; Zhang, S. Prediction of future malaria hotspots under climate change in sub-Saharan Africa. Clim. Chang. 2017, 143, 415-428. [CrossRef]

6. Hoegh-Guldberg, O.; Jacob, D.; Taylor, M.; Bindi, M.; Brown, S.; Camilloni, I.; Diedhiou, A.; Djalante, R.; Ebi, K.L.; Engelbrecht, F.; et al. Impacts of $1.5^{\circ} \mathrm{C}$ Global Warming on Natural and Human Systems; IPCC Secretariat: Geneva, Switzerland, 2019.

7. Rebaudo, F.; Struelens, Q.; Dangles, O. Modelling temperature-dependent development rate and phenology in arthropods: The devRate package for r. Methods Ecol. Evol. 2018, 9, 1144-1150. [CrossRef]

8. Paaijmans, K.P.; Blanford, S.; Bell, A.S.; Blanford, J.I.; Read, A.F.; Thomas, M.B. Influence of climate on malaria transmission depends on daily temperature variation. Proc. Natl. Acad. Sci. USA 2010, 107, 15135-15139. [CrossRef]

9. Villena, O.C.; Ryan, S.J.; Murdock, C.C.; Johnson, L.R. Temperature impacts the transmission of malaria parasites by Anopheles gambiae and Anopheles stephensi mosquitoes. bioRxiv 2020. [CrossRef]

10. Shapiro, L.L.M.; Whitehead, S.A.; Thomas, M.B. Quantifying the effects of temperature on mosquito and parasite traits that determine the transmission potential of human malaria. PLoS Biol. 2017, 15, e2003489. [CrossRef]

11. Christiansen-Jucht, C.; E Parham, P.; Saddler, A.; Koella, J.C.; Basañez, M.-G. Temperature during larval development and adult maintenance influences the survival of Anopheles gambiae s.s. Parasites Vectors 2014, 7, 489. [CrossRef]

12. Huang, J.; Walker, E.D.; Vulule, J.; Miller, J.R. Daily temperature profiles in and around Western Kenyan larval habitats of Anopheles gambiae as related to egg mortality. Malar. J. 2006, 5, 87. [CrossRef]

13. Hodjati, M.H.; Curtis, C.F. Effects of permethrin at different temperatures on pyrethroid-resistant and susceptible strains of Anopheles. Med Veter- Èntomol. 1999, 13, 415-422. [CrossRef]

14. Glunt, K.D.; Oliver, S.V.; Hunt, R.H.; Paaijmans, K.P. The impact of temperature on insecticide toxicity against the malaria vectors Anopheles arabiensis and Anopheles funestus. Malar. J. 2018, 17, 1-8. [CrossRef] [PubMed]

15. Glunt, K.D.; Paaijmans, K.P.; Read, A.F.; Thomas, M.B. Environmental temperatures significantly change the impact of insecticides measured using WHOPES protocols. Malar. J. 2014, 13, 1-11. [CrossRef] [PubMed]

16. Pu, J.; Wang, Z.; Chung, H. Climate change and the genetics of insecticide resistance. Pest Manag. Sci. 2019, 76, 846-852. [CrossRef] [PubMed]

17. Ayala, D.; Ullastres, A.; Gonzãjlez, J. Adaptation through chromosomal inversions in Anopheles. Front. Genet. 2014, 5, 129. [CrossRef] [PubMed]

18. Dobzhansky, T.; Dobzhansky, T.G. Genetics of the Evolutionary Process; Columbia University Press: New York, NY, USA, 1971; Volume 139.

19. Kirkpatrick, M. How and Why Chromosome Inversions Evolve. PLoS Biol. 2010, 8, e1000501. [CrossRef]

20. Cassone, B.J.; Molloy, M.J.; Cheng, C.; Tan, J.C.; Hahn, M.W.; Besansky, N.J. Divergent transcriptional response to thermal stress by Anopheles gambiae larvae carrying alternative arrangements of inversion 2La. Mol. Ecol. 2011, 20, 2567-2580. [CrossRef] 
21. Coluzzi, M.; Sabatini, A.; Petrarca, V.; Di Deco, M. Chromosomal differentiation and adaptation to human environments in the Anopheles gambiae complex. Trans. R. Soc. Trop. Med. Hyg. 1979, 73, 483-497. [CrossRef]

22. Wondji, C.; Simard, F.; Petrarca, V.; Etang, J.; Santolamazza, F.; Della Torre, A.; Fontenille, D. Species and Populations of theAnopheles gambiaeComplex in Cameroon with Special Emphasis on Chromosomal and Molecular Forms ofAnopheles gambiaes.s. J. Med Èntomol. 2005, 42, 998-1005. [CrossRef]

23. Riehle, M.M.; Bukhari, T.; Gneme, A.; Guelbeogo, W.M.; Coulibaly, B.; Fofana, A.; Pain, A.; Bischoff, E.; Renaud, F.; Beavogui, A.H.; et al. The Anopheles gambiae 2La chromosome inversion is associated with susceptibility to Plasmodium falciparum in Africa. eLife 2017, 6, e25813. [CrossRef] [PubMed]

24. Fouet, C.; Gray, E.; Besansky, N.J.; Costantini, C. Adaptation to Aridity in the Malaria Mosquito Anopheles gambiae: Chromosomal Inversion Polymorphism and Body Size Influence Resistance to Desiccation. PLOS ONE 2012, 7, e34841. [CrossRef] [PubMed]

25. Gray, E.M.; Rocca, K.A.C.; Costantini, C.; Besansky, N.J. Inversion 2La is associated with enhanced desiccation resistance in Anopheles gambiae. Malar. J. 2009, 8, 215. [CrossRef] [PubMed]

26. Rocca, K.A.C.; Gray, E.M.; Costantini, C.; Besansky, N.J. 2La chromosomal inversion enhances thermal tolerance of Anopheles gambiae larvae. Malar. J. 2009, 8, 147. [CrossRef]

27. Brooke, B.; Hunt, R.H.; Coetzee, M. Resistance to dieldrin + fipronil assorts with chromosome inversion 2La in the malaria vector Anopheles gambiae. Med Veter- Èntomol. 2000, 14, 190-194. [CrossRef] [PubMed]

28. Reidenbach, K.R.; Cheng, C.; Liu, F.; Liu, C.; Besansky, N.J.; Syed, Z. Cuticular differences associated with aridity acclimation in African malaria vectors carrying alternative arrangements of inversion 2La. Parasites Vectors 2014, 7, 176. [CrossRef]

29. Ayala, D.; Zhang, S.; Chateau, M.; Fouet, C.; Morlais, I.; Costantini, C.; Hahn, M.W.; Besansky, N.J. Association mapping desiccation resistance within chromosomal inversions in the African malaria vector Anopheles gambiae. Mol. Ecol. 2018, 28, 1333-1342. [CrossRef]

30. VanHook, A.M. Understanding hygrosensation: How flies sense changes in humidity. Sci. Signal. 2016, 9, ec127. [CrossRef]

31. Enjin, A.; Zaharieva, E.E.; Frank, D.D.; Mansourian, S.; Suh, G.S.; Gallio, M.; Stensmyr, M.C. Humidity Sensing in Drosophila. Curr. Biol. 2016, 26, 1352-1358. [CrossRef]

32. White, B.J.; Hahn, M.W.; Pombi, M.; Cassone, B.J.; Lobo, N.F.; Simard, F.; Besansky, N.J. Localization of Candidate Regions Maintaining a Common Polymorphic Inversion (2La) in Anopheles gambiae. PLoS Genet. 2007, 3, e217. [CrossRef]

33. Ibrahim, S.S.; Mukhtar, M.M.; Datti, J.A.; Irving, H.; Kusimo, M.O.; Tchapga, W.; Lawal, N.; Sambo, F.I.; Wondji, C.S. Temporal escalation of Pyrethroid Resistance in the major malaria vector Anopheles coluzzii from Sahelo-Sudanian Region of northern Nigeria. Sci. Rep. 2019, 9, 7395. [CrossRef]

34. Ibrahim, S.S.; Mukhtar, M.M.; Irving, H.; Labbo, R.; Kusimo, M.O.; Mahamadou, I.; Wondji, C.S. High Plasmodium infection and multiple insecticide resistance in a major malaria vector Anopheles coluzzii from Sahel of Niger Republic. Malar. J. 2019, 18, 181. [CrossRef]

35. Ibrahim, S.S.; A Manu, Y.; Tukur, Z.; Irving, H.; Wondji, C.S. High frequency of kdr L1014F is associated with pyrethroid resistance in Anopheles coluzzii in Sudan savannah of northern Nigeria. BMC Infect. Dis. 2014, 14, 1-8. [CrossRef] [PubMed]

36. Gillies, M.; Coetzee, M. A supplement to anophelinae of Africa south of Sahara (Afro-tropical region). Publ. South Afr. Inst. Med. Res. 1987, 55, 1-143.

37. Livak, K.J. Organization and Mapping of a Sequence on the Drosophila Melanogaster X and Y Chromosomes That Is Transcribed during Spermatogenesis. Genetics 1984, 107, 611-634. [CrossRef] [PubMed]

38. Santolamazza, F.; Mancini, E.; Simard, F.; Qi, Y.; Tu, Z.; Della Torre, A. Insertion polymorphisms of SINE200 retrotransposons within speciation islands of Anopheles gambiae molecular forms. Malar. J. 2008, 7, 163. [CrossRef] [PubMed]

39. Benedict, M.Q.; Cockburn, A.; A Seawright, J. Heat-shock mortality and induced thermotolerance in larvae of the mosquito Anopheles albimanus. J. Am. Mosq. Control. Assoc. 1991, 7, 547-550.

40. Oliver, S.V.; Brooke, B.D. The effect of elevated temperatures on the life history and insecticide resistance phenotype of the major malaria vector Anopheles arabiensis (Diptera: Culicidae). Malar. J. 2017, 16, 73. [CrossRef]

41. WHO. Guidelines for Laboratory and Field Testing of Mosquito Larvicides; World Health Organization: Geneva, Switzerland, 2005; pp. $1-41$.

42. WHO. Test Procedures for Insecticide Resistance Monitoring in Malaria Vector Mosquitoes; World Health Organization: Geneva, Switzerland, 2013; ISBN 97892415051544.

43. White, B.J.; Besansky, N.J.; Grushko, O.; Della Torre, A.; Sharakhov, I.; Brengues, C.; Kayondo, J.K.; Santolamazza, F.; Simard, F.; Pombi, M.; et al. Molecular Karyotyping of the 2La Inversion in Anopheles Gambiae. Am. J. Trop. Med. Hyg. 2007, 76, 334-339. [CrossRef]

44. Sharakhov, I.V.; White, B.J.; Kayondo, J.; Lobo, N.F.; Santolamazza, F.; della Torre, A.; Simard, F.; Collins, F.H.; Besansky, N.J. Breakpoint structure reveals the unique origin of an interspecific chromosomal inversion (2La) in the Anopheles gambiae complex. Proc. Natl. Acad. Sci. USA 2006, 103, 6258-6262. [CrossRef]

45. Dahlgaard, J.; Loeschcke, V.; Michalak, P.; Justesen, J. Induced thermotolerance and associated expression of the heat-shock protein Hsp70 in adultDrosophila melanogaster. Funct. Ecol. 1998, 12, 786-793. [CrossRef]

46. Adedeji, E.O.; Ogunlana, O.O.; Fatumo, S.; Beder, T.; Ajamma, Y.; Koenig, R.; Adebiyi, E. Anopheles metabolic proteins in malaria transmission, prevention and control: A review. Parasites Vectors 2020, 13, 1-30. [CrossRef] [PubMed] 
47. Benoit, J.B.; Lopez-Martinez, G.; Patrick, K.R.; Phillips, Z.P.; Krause, T.B.; Denlinger, D.L. Drinking a hot blood meal elicits a protective heat shock response in mosquitoes. Proc. Natl. Acad. Sci. USA 2011, 108, 8026-8029. [CrossRef]

48. Greppi, C.; Laursen, W.J.; Budelli, G.; Chang, E.C.; Daniels, A.M.; van Giesen, L.; Smidler, A.L.; Catteruccia, F.; Garrity, P.A. Mosquito heat seeking is driven by an ancestral cooling receptor. Science 2020, 367, 681-684. [CrossRef]

49. Lü, X.; Han, S.-C.; Li, Z.-G.; Li, L.-Y.; Li, J. Gene Characterization and Enzymatic Activities Related to Trehalose Metabolism of In Vitro Reared Trichogramma dendrolimi Matsumura (Hymenoptera: Trichogrammatidae) under Sustained Cold Stress. Insects 2020, 11, 767. [CrossRef]

50. Riveron, J.M.; Ibrahim, S.S.; Chanda, E.; Mzilahowa, T.; Cuamba, N.; Irving, H.; Barnes, K.G.; Ndula, M.; Wondji, C.S. The highly polymorphic CYP6M7 cytochrome P450 gene partners with the directionally selected CYP6P9a and CYP6P9b genes to expand the pyrethroid resistance front in the malaria vector Anopheles funestus in Africa. BMC Genom. 2014, 15, 1-19. [CrossRef]

51. Schmittgen, T.D.; Livak, K.J. Analyzing real-time PCR data by the comparative C(T) method. Nat. Protoc. 2008, 3, 1101-1108. [CrossRef]

52. Fadel, A.N.; Ibrahim, S.S.; Tchouakui, M.; Terence, E.; Wondji, M.J.; Tchoupo, M.; Wanji, S.; Wondji, C.S. A combination of metabolic resistance and high frequency of the $1014 \mathrm{~F} \mathrm{kdr}$ mutation is driving pyrethroid resistance in Anopheles coluzzii population from Guinea savanna of Cameroon. Parasites Vectors 2019, 12, 263. [CrossRef]

53. Ibrahim, S.S.; Fadel, A.N.; Tchouakui, M.; Terence, E.; Wondji, M.J.; Tchoupo, M.; Kérah-Hinzoumbé, C.; Wanji, S.; Wondji, C.S. High insecticide resistance in the major malaria vector Anopheles coluzzii in Chad Republic. Infect. Dis. Poverty 2019, 8, 1-12. [CrossRef] [PubMed]

54. E Sinka, M.; Bangs, M.J.; Manguin, S.; Coetzee, M.; Mbogo, C.M.; Hemingway, J.; Patil, A.P.; Temperley, W.H.; Gething, P.W.; Kabaria, C.W.; et al. The dominant Anopheles vectors of human malaria in Africa, Europe and the Middle East: occurrence data, distribution maps and bionomic précis. Parasites Vectors 2010, 3, 117. [CrossRef] [PubMed]

55. Onyabe, D.Y.; E Conn, J. The distribution of two major malaria vectors, Anopheles gambiae and Anopheles arabiensis, in Nigeria. Memórias do Instituto Oswaldo Cruz 2001, 96, 1081-1084. [CrossRef]

56. Ranson, H.; Abdallah, H.; Badolo, A.; Guelbeogo, W.M.; Kerah-Hinzoumbe, C.; Yangalbe-Kalnone, E.; Sagnon, N.; Simard, F.; Coetzee, M. Insecticide resistance in Anopheles gambiae: Data from the first year of a multi-country study highlight the extent of the problem. Malar. J. 2009, 8, 299. [CrossRef] [PubMed]

57. Gimonneau, G.; Bouyer, J.; Morand, S.; Besansky, N.J.; Diabate, A.; Simard, F. A behavioral mechanism underlying ecological divergence in the malaria mosquito Anopheles gambiae. Behav. Ecol. 2010, 21, 1087-1092. [CrossRef] [PubMed]

58. Dao, A.; Yaro, A.S.; Diallo, M.; Timbiné, S.; Huestis, D.L.; Kassogué, Y.; Traoré, A.I.; Sanogo, Z.L.; Samaké, D.; Lehmann, T. Signatures of aestivation and migration in Sahelian malaria mosquito populations. Nat. Cell Biol. 2014, 516, 387-390. [CrossRef] [PubMed]

59. Lehmann, T.; Weetman, D.; Huestis, D.L.; Yaro, A.S.; Kassogue, Y.; Diallo, M.; Donnelly, M.J.; Dao, A. Tracing the origin of the early wet-seasonAnopheles coluzziiin the Sahel. Evol. Appl. 2017, 10, 704-717. [CrossRef] [PubMed]

60. Huestis, D.L.; Artis, M.L.; Armbruster, P.A.; Lehmann, T. Photoperiodic responses of Sahelian malaria mosquitoes Anopheles coluzzii and An. arabiensis. Parasites Vectors 2017, 10, 621. [CrossRef] [PubMed]

61. Nguyen, V.T.; Morange, M.; Bensaude, O. Protein denaturation during heat shock and related stress. Escherichia coli betagalactosidase and Photinus pyralis luciferase inactivation in mouse cells. J. Biol. Chem. 1989, 264, 10487-10492. [CrossRef]

62. Glunt, K.D.; Blanford, J.I.; Paaijmans, K.P. Chemicals, Climate, and Control: Increasing the Effectiveness of Malaria Vector Control Tools by Considering Relevant Temperatures. PLOS Pathog. 2013, 9, e1003602. [CrossRef]

63. Matoke-Muhia, D.; Gimnig, J.E.; Kamau, L.; Shililu, J.; Bayoh, M.N.; Walker, E.D. Decline in frequency of the 2La chromosomal inversion in Anopheles gambiae (s.s.) in Western Kenya: correlation with increase in ownership of insecticide-treated bed nets Parasites Vectors 2016, 9, 334. [CrossRef]

64. Labbé, P.; Berticat, C.; Berthomieu, A.; Unal, S.; Bernard, C.; Weill, M.; Lenormand, T. Forty Years of Erratic Insecticide Resistance Evolution in the Mosquito Culex pipiens. PLoS Genet. 2007, 3, e205. [CrossRef]

65. Nigatu, W.; Curtis, C.F.; Lulu, M. Test for association of DDT resistance with inversion polymorphism in Anopheles arabiensis from Ethiopia. J. Am. Mosq. Control. Assoc. 1995, 11, 238-240.

66. Brooke, B.; Hunt, R.H.; Chandre, F.; Carnevale, P.; Coetzee, M. Stable Chromosomal Inversion Polymorphisms and Insecticide Resistance in the Malaria Vector MosquitoAnopheles gambiae (Diptera: Culicidae). J. Med Ėntomol. 2002, 39, 568-573. [CrossRef]

67. Love, R.R.; Steele, A.M.; Coulibaly, M.B.; Traore, S.F.; Emrich, S.J.; Fontaine, M.; Besansky, N.J. Chromosomal inversions and ecotypic differentiation inAnopheles gambiae: the perspective from whole-genome sequencing. Mol. Ecol. 2016, 25, 5889-5906. [CrossRef]

68. Hoffmann, A.A.; Sørensen, J.G.; Loeschcke, V. Adaptation of Drosophila to temperature extremes: bringing together quantitative and molecular approaches. J. Therm. Biol. 2003, 28, 175-216. [CrossRef]

69. Loeschcke, V.; Krebs, R.A.; Barker, J.S.F. Genetic variation for resistance and acclimation to high temperature stress in Drosophila buzzatii. Biol. J. Linn. Soc. 1994, 52, 83-92. [CrossRef]

70. Feder, M.E.; Hofmann, G.E. HEAT-SHOCK PROTEINS, MOLECULAR CHAPERONES, AND THE STRESS RESPONSE: Evolutionary and Ecological Physiology. Annu. Rev. Physiol. 1999, 61, 243-282. [CrossRef]

71. Spring, J.H.; Robichaux, S.R.; Hamlin, J.A. The role of aquaporins in excretion in insects. J. Exp. Biol. 2009, 212, 358-362. [CrossRef]

72. Thompson, S.N. Trehalose-the insect 'blood'sugar. Adv. Insect Phys. 2003, 31, 205-285. 